\title{
THE «ARGENTINE FAILURE» FROM A COMPARATIVE PERSPECTIVE: THE ROLE OF TOTAL FACTOR PRODUCTIVITY*
}

\author{
GERMÁN H. GONZÁLEZ \\ Instituto de Investigaciones Económicas y Sociales del Sur ${ }^{a}$ \\ VALENTINA N. VIEGO \\ Universidad Nacional del Sur ${ }^{\text {a }}$
}

\begin{abstract}
The paper proposes an interpretation of the «Argentine failure» based on development accounting and econometrical approaches frequently used in the current cross-country income differentials literature. The main results are as follows: the development process of Canada - in term of per capita GDP - moved away from that of Argentina around 1918, but there was a structural change in the determinants of aggregate productivity around 1935 that led Argentina to take a diverging path. Recovery - thanks to improved aggregate productivity - was not possible after 1940. The results support the idea that Argentina fell into a "staple trap», while Canada embarked on a successful path due to the adjacency and political proximity with a larger and complementary economy.
\end{abstract}

Keywords: Argentine failure, staple trap, productivity, Argentina, Canada

JEL Code: N10, O47, N16, N46, N56, O57

* Received 20 October 2010. Accepted 1 July 2011. We gratefully acknowledge the financial support of the Understanding Canada Program (Foreign Affairs and International Trade Canada). We are thankful to Alexis Esposto (Swinburne University of Technology), Yovanna Pineda (University of Central Florida), Pablo Gerchunoff (Universidad Torcuato di Tella), Fernando Tohmé (IIESS and Universidad Nacional del Sur) and David Sheinin (Trent University), the editors of the RHE/JILAEH and three anonymous referees for their useful suggestions. The paper reflects solely the opinions of the authors.

a Departamento de Economía, Instituto de Investigaciones Económicas y Sociales del Sur (IIESS, CONICET-UNS), Universidad Nacional del Sur. 12 de Octubre $1198,7^{\circ}$ piso. D8000CTX Bahía Blanca, Argentina. ghgonza@uns.edu.ar; vviego@uns.edu.ar 


\section{RESUMEN}

El artículo ofrece una interpretación al «Fracaso Argentino» basado en el enfoque de contabilidad del desarrollo y la econometría, frecuentemente utilizados en la literatura actual que explica los diferenciales en el ingreso per capita. El proceso de desarrollo canadiense se alejó del argentino alrededor de 1918. Sin embargo, estas economías experimentaron un cambio estructural en los determinantes de la productividad agregada alrededor de 1935 que llevó a que también sean divergentes en términos tecnológicos. A partir de 1940, la recuperación argentina no fue posible. Se ofrece soporte técnico a la idea que sostiene que Argentina cayó en una "staple trap», mientras Canadá ingresó en un sendero exitoso debido a su adyacencia y proximidad política con una economía mayor y complementaria.

Palabras clave: fracaso Argentino, staple trap, productividad, Argentina, Canadá

\section{INTRODUCTION}

Comparative studies between countries allow us to identify questions or problems that are often underestimated or go unnoticed. The contrast offers, above all, the opportunity for improved understanding of the causes of success or failure, the dissimilar impact of environmental or human factors, as well as other important contributing factors.

It is obvious that the development process of Canada moved away from that of Argentina. The point in time at which this process began is debatable. Nevertheless, it is possible to suggest that at some point between the wars Canada reached an advanced stage of industrialisation, whereas Argentina began to fall behind.

Both countries followed similar models of development and used comparable political instruments, but with different economic and social outcomes. These outcomes could be the result of timing, design, social or political peculiarities, an accident of history or some exogenous factor. In the analysis that follows, we show quantitatively the more statistically significant elements using a development accounting framework (Hsieh and Klenow 2010) and an econometrics approach following the current literature on cross-country income differentials (Rodrik 2003).

The principal results are the following. We found a break point in the relative per capita GDP in 1918, and observed that its principal component after this year - the relative technological performance - experiences a structural change in 1940. It is possible to state that the dissimilar geographical and, probably, political attitude towards the United States during 
the 1930s and later explain the divergent technological path. We found that the determinants of the relative technological performance suffer a structural change in 1935 and the result seems to support this hypothesis.

The paper contains five sections. The section 2 reviews the "Argentine failure» in a comparative sense. Section 3 introduces the methodology, while section 4 presents empirical results and is followed by a discussion in section 5 .

\section{THE «ARGENTINE FAILURE»: A COMPARATIVE PERSPECTIVE}

From the 1870s to the 1930s, Argentina experienced extraordinarily dynamic macroeconomic performance. Both income and income per capita grew at rates comparable to countries that are today considered to be developed. Between 1900 and 1930, its gross domestic product per capita (per capita GDP) did not show notable differences with the per capita GDP of Austria, Germany, France and Sweden. Its performance was better than that of some other economies, particularly Italy and Spain (Figure 1(a)). As pointed out by della Paolera and Taylor, «Argentina's 1913 income level was clearly in the world top ten, and almost the top five. Whatever its exact status in 1913, for all practical purposes Argentina was an advanced country (2003, p. 3)». Similar to other newly settled countries, Argentina received substantial foreign direct investment and massive labour immigration from Europe. Although the per capita GDPs of the United States, Australia and New Zealand were always above those of Canada and Argentina, all these countries seemed to be in the same "convergence club» ${ }^{1}$ (see Figure 1(b)).

Until the 1930s, the picture changed regardless of whether the break point was effective in these years. Moreover, the annual data of Argentina's economic performance since the end of the World War II (WWII) show that the country took a diverging path compared to the evolution of the set of economies with similar origin. Argentina's ratio to Organisation for Economic Co-operation and Development income fell from 80 per cent in 1913 to 65 per cent in 1973, and a mere 43 per cent in 1987 (della Paolera and Taylor 2003). Miguez (2005, p. 483) points out that between 1913 and 1989 Argentina grew at 0.74 per cent annually, while the worldwide economy grew at 2 per cent per annum.

In order to compare the different paths of development, we analyse data on per capita GDP of Argentina and Canada relative to the United States and then Argentina, taking Canada as the benchmark. More specifically,

$$
u_{i t}=\frac{\text { per capita GDP of Country i in year } t}{\text { Benchmark per capita GDP in year } t}
$$

\footnotetext{
${ }^{1}$ See Galor (1996) for clarification regarding the convergence hypotheses.
} 
FIGURE 1

PER CAPITA GDP, A COMPARATIVE VIEW (1990 INTERNATIONAL

GEARY-KHAMIS DOLLARS)
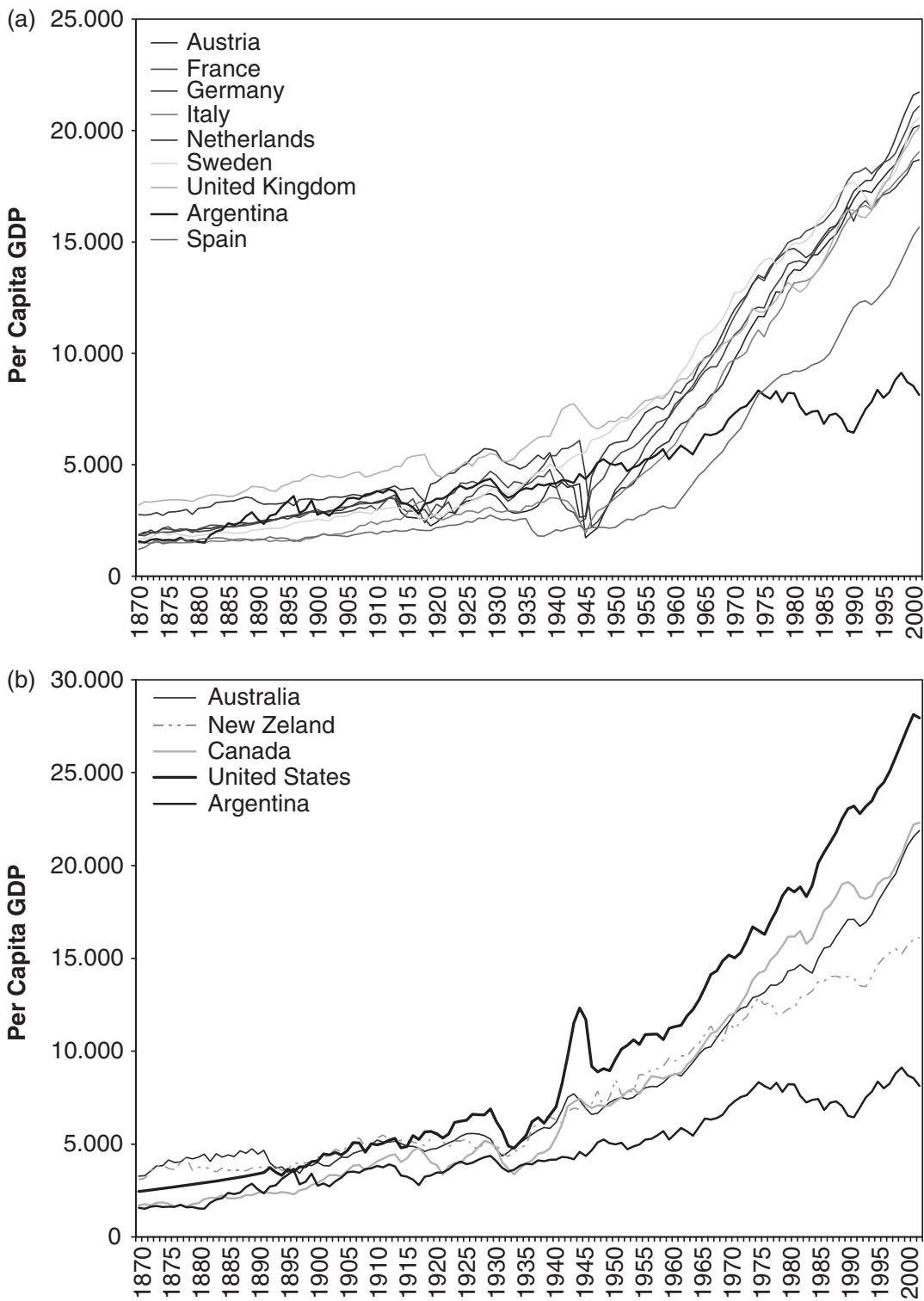

Source: Maddison (2006) and Ferreres (2005). 
where the role of country $i$ is occupied by Canada or Argentina, and the benchmark is the United States or Canada.

Figure 2 plots the evolution of $u_{i t}$ between 1870 and 2000. It seems to show the existence of at least two long, dissimilar periods: one lasting from the end of the $19^{\text {th }}$ century to the mid-1930s, the other starting in the mid1930s and lasting until the present day. The first is characterised by a similar path of relative performance, and the other shows Canada catching up while Argentina is falling behind the United States and Canada.

\section{METHODOLOGY: DEVELOPMENT ACCOUNTING APPROACH}

In Caselli (2005, p. 681), we find a synopsis of what economists generally refer to as development accounting: it «uses cross-country data on output and inputs, at one point in time, to assess the relative contribution of differences in factor quantities, and differences in the efficiency with which those factors are used, to these vast differences in per-worker incomes». We consider, in line with Hall and Jones (1997), that growth research has not provided effective explanations for the extreme diversity in income across countries, and thus the study of economic activity levels could give complementary insights.

Our departure point is the development accounting exercises performed by Mankiw et al. (1992), and discussed by Klenow and Rodriguez-Claire (1997), Hall and Jones (1999) and, more recently, by Hsieh and Klenow (2010). Accordingly, we consider the following aggregate production function with constant returns,

$$
Y=K^{\alpha} H^{\beta}(A L)^{1-\alpha-\beta}
$$

where $Y$ represents output, $K$ the (total) stock of physical capital, $A$ is a productivity index and $L$ is the number of (employed) workers in the economy. The total stock of human capital is the product of the average level of human capital, $h$, and the number of workers $(H=h \times L)$. This production function can be rearranged as

$$
\frac{Y}{L}=\left(\frac{K}{Y}\right)^{\frac{\alpha}{1-\alpha-\beta}}\left(\frac{H}{Y}\right)^{\frac{\beta}{1-\alpha-\beta}} A .
$$

In order to consider per capita income instead of per worker income, let $P$ be total population ${ }^{2}$.

2 Blyde and Fernández-Arias (2005), Manuelli (2005) and González et al. (2011) used a similar expression, while Hopenhayn and Neumeyer (2004) used income per worker to explain Latin American performance relative to developed countries. 
FIGURE 2

PERFORMANCE OF ARGENTINA AND CANADA RELATIVE TO UNITED STATES, AND ARGENTINE PERFORMANCE RELATIVE TO CANADA
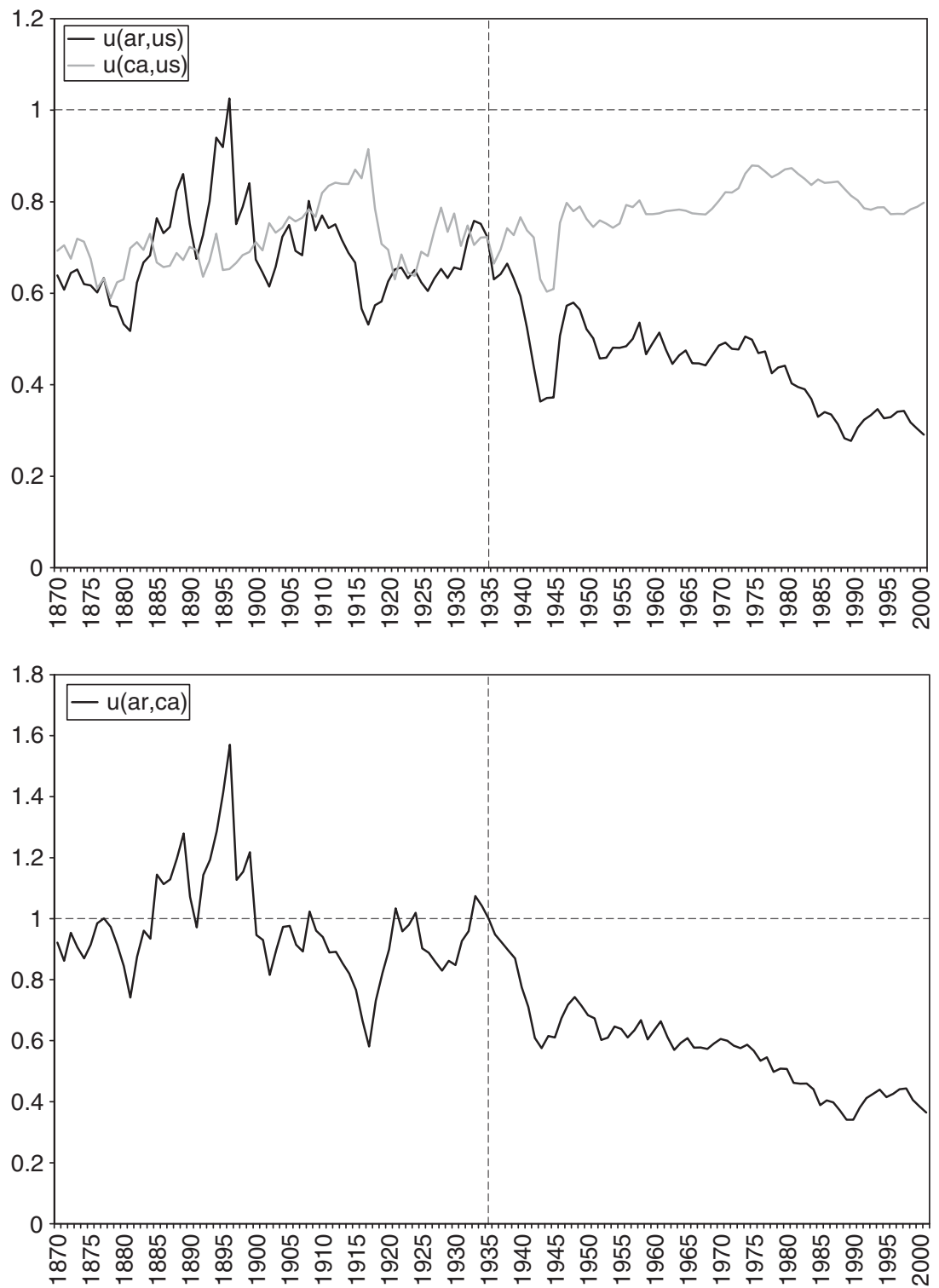

Source: Maddison (2006) and Ferreres (2005). 
Using the relationship

$$
\frac{Y}{P}=\frac{L}{P} \times \frac{Y}{L},
$$

the production function is rewritten as

$$
\frac{Y}{P}=\frac{L}{P}\left(\frac{K}{Y}\right)^{\frac{\alpha}{1-\alpha-\beta}}\left(\frac{H}{Y}\right)^{\frac{\beta}{1-\alpha-\beta}} A
$$

where $Y / P$ is the per capita income and $L / P$ is the employment rate; $K / Y$ and $H / Y$ express physical and human capital intensities. The combined effect of the three components can be interpreted as the effect of factor accumulation (Hall and Jones 1999). We follow King and Levine (1994) and use the Perpetual Inventory Method with steady-state estimates of initial capital in the construction of $K$ series, and we follow Mankiw et al. (1992) to compute the human capital intensity. Sources and the estimation process for human and physical capital stocks are presented in the appendix.

The last component in equation [5] is the productivity index or total factor productivity (TFP), which partially reflects the level of technology. However, this variable can also easily capture the unemployment of the available stock of physical and human capital and technological inefficiencies. Whereas resource unemployment could be considered as an important measurement error in some studies, it is relatively unimportant for us. Like Blyde and Fernández-Arias (2005), we are more interested in the explanation of long-run gaps between countries than in cyclical variations in the utilisation of the production factors.

Thus, it is possible to undertake development accounting on the basis of the above production function. That is, we can take the ratio of two national measures of per capita income using equation [5]:

$$
u_{i j} \equiv \frac{Y_{i} / P_{i}}{Y_{j} / P_{j}}=\frac{L_{i} / P_{i}}{L_{j} / P_{j}}\left(\frac{K_{i} / Y_{i}}{K_{j} / Y_{j}}\right)^{\frac{\alpha}{1-\alpha-\beta}}\left(\frac{H_{i} / Y_{i}}{H_{j} / Y_{j}}\right)^{\frac{\beta}{1-\alpha-\beta}} \frac{A_{i}}{A_{j}} .
$$

Given data on relative quantities of factor production and specific values of $\alpha$ and $\beta$, we can measure cross-country differences in productivity, $A_{i} / A_{j}$, as residuals:

$$
\frac{A_{i}}{A_{j}}=\frac{\frac{Y_{i}}{P_{i}} / \frac{Y_{i}}{P j}}{\left[\frac{L_{i}}{P_{i}} / \frac{L_{i}}{P_{j}}\right]\left[\frac{K_{i}}{Y_{i}} / \frac{K_{i}}{Y_{j}}\right]^{\frac{\alpha}{1-\alpha-\beta}}\left[\frac{H_{i}}{Y_{i}} / \frac{H_{j}}{Y_{j}}\right]^{\frac{\beta}{1-\alpha-\beta}}} .
$$

To describe the extent to which labour, physical and human capital and productivity account for cross-country differences in per capita income, we 
begin by presenting the following indicators:

$$
\rho_{L P i j}=\frac{L_{i} / P_{i}}{L_{j} / P_{j}} ; \rho_{K Y i j}=\left(\frac{K_{i} / Y_{i}}{K_{j} / Y_{j}}\right)^{\frac{\alpha}{1-\alpha-\beta}} ; \rho_{H Y i j}=\left(\frac{H_{i} / Y_{i}}{H_{j} / Y_{j}}\right)^{\frac{\beta}{1-\alpha-\beta}} ; \rho_{A i j}=\frac{A_{i}}{A_{j}} \text {. }
$$

Values more distant from unity indicate larger differences in the component. For example, with $i=$ Argentina and $j=$ Canada, if $\rho_{K Y i j}<1$ means that the intensity of physical capital in Canada is greater than that for Argentina. Thus, the evolution of these ratios shows us which component is more relevant to explain the divergent paths. Once the most important component has been identified, we can focus on the explanation of its behaviour.

\section{EMPIRICAL RESULTS}

To conduct this analysis, we first compute the relative performance, $u$, and then calculate the contribution of each component of the aggregate production function to this relative performance, $\rho_{A i j}$. We calibrate the production function keeping $\alpha=0.30$ and $\beta=0.28 \quad(1-\alpha-\beta=0.42)$, as did Mankiw et al. (1992) and Klenow and Rodriguez-Claire (1997) ${ }^{3}$. We used a sample of 100 years (1895-1995) for the exercise of development accounting. The sources for the raw data are described in the Appendix.

It is important to note that we conceive the "Argentine failure» not as a point in time, but as a process. If we rely on the relative per capita GDP figure, we could say that Argentina fell behind Canada around the mid-1930s. In particular, in 1936 the relative per capita GDP was 0.97, after this measure declined monotonically. However, it is possible to locate the moment these economies began to diverge using time series analysis. After a precise review of the literature and using an eclectic approach, Sanz-Villarroya (2005) found two break points in the relative per capita GDP in 1896 and 1918. She argued that the first of these indicates «the break in the catching-up trend

\footnotetext{
3 Véganzonès and Winograd (1998) used the same $\alpha$ for a comparative historical study of Argentina and the United States of America. Blyde and Fernández-Arias (2005) used a capital income share of $1 / 3$, but their sensibility analysis showed no qualitative differences in the results when they used a capital share of 0.4 or 0.5 . Manuelli (2005) mentioned that the analysis of individual Latin American country studies suggests values of $\alpha$ ranging from 0.3 to 0.7 and cites Gollin (2002)'s advice about adjusting the estimate of capital share downward because of measurement problems. Katz et al. (2007) compute the participation of labour in the Argentinean product following Gollin's methodology and obtain the value of 0.52 for our $1-\alpha-\beta$ parameter. However, they specify a production function without human capital and this value is not directly applicable. Hence, although we recognise some possible bias coming from model specification or measurement problems, the specialised literature lets us assume that its magnitude is low. The working paper of this document presents a sensibility test using five models with different parameter values showing that the conclusions are similar (González and Viego, 2008).
} 
FIGURE 3

EVOLUTION OF EACH INDICATOR $\rho \bullet$ VIS-À-VIS THE RELATIVE PER CAPITA GDP

(a)

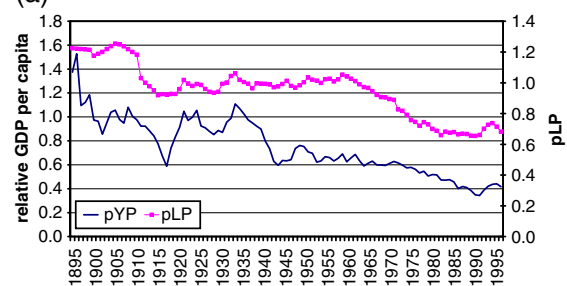

(c)

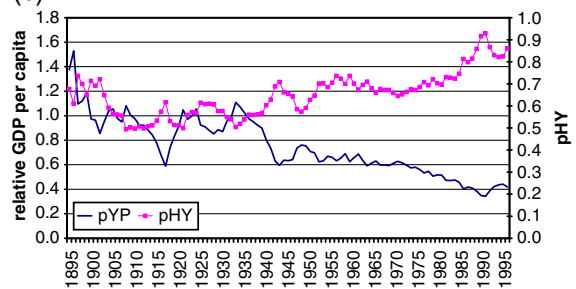

(b)

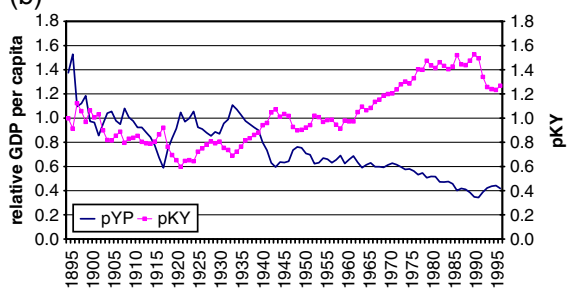

(d)

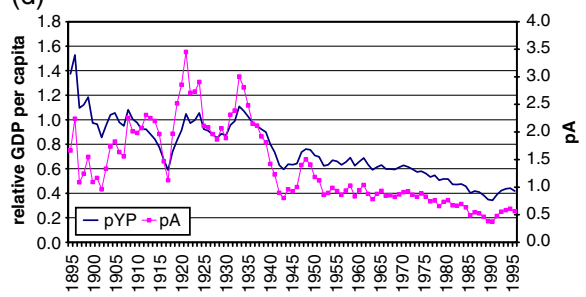

Source: Authors' estimations.

between the economies» (p. 449), while the second indicates a positive change in level but «it does not affect the trend initiated in 1896» (p. 450). On the contrary, our estimates based on the methodology proposed by Zivot and Andrews (1992) and allowing for breaks in both intercept and trend, or only intercept, found the break point in 1918 (Minimum $t$-statistic: -5.899 , and critical value at 1 per cent: -5.57$)^{4}$. Relying on these last results, we began the analysis of the decomposition of relative per capita GDP dividing the sample into two periods of analysis: 1895-1918 and 1919-1995.

Figure 3 plots the evolution of the decomposition of the relative per capita GDP between Argentina and Canada. The evolution of each indicator $\rho_{\bullet}$ is compared with the evolution of the relative per capita GDP. Each graph in

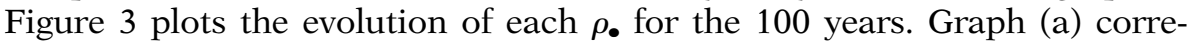
sponds to $\rho_{L P}$. Its evolution showed a high similitude with relative per capita GDP, but its value is close to 1 between 1911 and 1966. This means that this component does not explain the great fall in the relative per capita GDP between these years (35 per cent) despite the high correlation between both indicators for the whole period ( 82 per cent) and subperiods (72 and 75 per cent, respectively).

${ }^{4}$ When we supposed a break in trend only, a break point was found in 1934. Nevertheless, the model with breaks in both intercept and trend is preferable according to Sen (2003). We could neither confirm nor reject the break in 1896 because our data set covers the period 1895-1995. 
The evolutions of $\rho_{K Y}$ and $\rho_{H Y}$ show a high similitude with each other for the whole period and a lower similitude with relative per capita GDP in the first subperiod (see graphs (B) and (C) in Figure 3). The break point set in 1918 could be captured by a change in the process of accumulation of physical and human capital. After 1918, these indicators show a process completely inverse to relative per capita $\mathrm{GDP}^{5}$. This means that the explanation of the differences in the process of accumulation of capital allows us to understand part of the evolution of relative per capita GDP between 1895 and 1918, but the sources of the posterior behaviour must be looked for in the evolution of relative productivity.

Graph (D) plots the evolution of $\rho_{A}$ vis-à-vis the relative per capita GDP. While the technological differences between the two countries seem to have the lowest explanation power of all the components for the period 1895-1918 (the correlation coefficient is 17 per cent), the situation changes for the following subperiod (the correlation rate reached 95 per cent). However, the comparison of the figures alerts us to the possibility of a break point posterior to the structural break in relative per capita GDP. Applying the test of Zivot and Andrews (1992) on the series $\rho_{A}$, and allowing for breaks in both intercept and trend, we found the break point in 1940 (minimum $t$-statistic: -6.058 , and critical value at 1 per cent: -5.57$)^{6}$.

A possible explanation of previous results is the following. The sources of the structural changes must be found in a decline in Canadian physical and human capital/product ratios ${ }^{7}$ counterweighed by improvements in global efficiency during those years. In contrast, Argentina increased physical capital intensity at the expense of efficiency and technology upgrading. Argentina's experience illustrates that capacity expansion (not only in equipment, but also in workers' formal education) must be accompanied by growing technological competencies; otherwise, inefficiencies would arise and per capita income stagnates or declines over time. These results are consistent with Véganzonès and Winograd (1998) who find a relatively low efficiency of the Argentine economy after 1933 with a slower adoption of foreign technological progress and weaker diffusion. After the end of WWII, Argentina continued increasing its physical capital intensity with severe losses in productivity. Meanwhile, Canada showed a notable increase of the human capital intensity ratio despite decreasing global productivity. See the Appendix for the graphs of the components of production functions by country.

5 The correlation rate between $\rho_{K Y}$ and $\rho_{H Y}$ is 82 per cent for the overall period, while between each one with relative per capita GDP are 26 per cent and 21 per cent, respectively, for the period 1895-1918; -92 per cent and -91 per cent for the period 1919-1995.

6 We found a break point in 1918 if only allowing a break in intercept and 1920 if only allowing a break in trend. However, both break points are significant at 5 per cent and the model allowing both breaks is preferable according to Sen (2003).

7 This is explained by a higher GDP growth rate compared to that of capital accumulation. 
This interpretation is consistent with Prados de la Escosura and SanzVillarroya (2009), who argued that the process of capital accumulation «does not seem to suffice for Argentina to maintain its position relative to other countries of new settlement since the 1960s. Her deepening divergence ... seems attributable to a slowdown in TFP growth (p. 16)».

As a result of the previous empirical exercise, we proceed to estimate a linear model to explain the technological gap. The ratio between technological levels of each country, $\rho_{A}$, is considered as the dependent variable. We discriminated three broad sets of explanatory variables following Rodrik (2003) and Acemoglu (2008), all of them taking as ratios Argentina vis-à-vis Canada: (i) differences in the quality of social infrastructure, defined as the set of laws, institutions, and government policies that make up the economic environment (Hall and Jones 1997); (ii) differences in terms of integration in the world economy; and (iii) dissimilar geographic aspects. The rationale behind these variables is explained in the next paragraph.

Hall and Jones (1997) argued that government supports productive activity by deterring private resource diversion and by abstaining from diverting itself. Here, government influence on the economy is captured by the weight of public expenditure on GDP. We also introduce two complementary variables that capture the institutional and economic stability. Following Prados de la Escosura y Sanz-Villarroya (2009), one of these is the "contract intensive money» and the other is the inflation rate. These authors argue that societies with property rights that are well defined and guaranteed show a larger proportion of their assets in deposit accounts and, consequently, better capital accumulation and long-run economic performance. We consider the possibility that the security of property rights could condition technological change, and hence aggregate productivity. In addition, macroeconomic mismanagement causes high inflation rates, which in turn negatively affect performance by distorting relative prices and alter the fundamental terms of long-term contracts.

The set of social infrastructure is completed with three alternative variables: the type of political regime, the polity index and an index of democratisation. We assume, like Engerman and Sokoloff (2003), that a weak democracy or an authoritarian regime may be more permeable to the influence of rent-seeking groups and elites.

The relevance of integration in the world economy has been extensively studied. It is accepted that there may not be an unambiguous link between trade and performance (Miller and Upadhyay 2000; Rodríguez and Rodrik 2000; González and Constantin, 2009). The literature notes the possibility of specialisation following the comparative advantages as a positive impact, together with the possibility of achieving economies of scale, and the absorption of foreign technological advance and improvement in managerial practices. However, Rodriguez (2005, p. 134) pointed out that «although trade barriers generate static efficiency losses that lower the steady state level 
of per capita GDP they can also raise production in industries that have positive externalities. Thus, if the forces of comparative advantage lead the economy to specialise away from technologically dynamic sectors that produce knowledge spillovers then trade restrictions may, by raising output of these industries, stimulate economic growth». Therefore, we introduce the average tariff as a measure of integration in the world economy without expectations about the sign.

The third set of determinants are "geographic differences that affect the environment in which individuals live and that influence the productivity of agriculture, the availability of natural resources, certain constraints on individual behaviour, or even individual attitudes» (Acemoglu 2008, p. 23). Argentina and Canada seem to have no relevant climate, geophysical, or resource-abundance differences. However, "two regions producing identical staples may follow quite different paths of development simply as a result of different social and economic infrastructures» (Altman 2003, p. 224). Furthermore, the distance between a country and its principal export market or the technological leader affects its performance. For instance, Kneller (2005) argues that the positive effect of frontier technology on domestic economies could vary with physical distance if the knowledge generated in one country is not instantaneously available without cost to all. For this reason, we introduce two measures: the aggregate productivity of the United States estimated by Véganzonès and Winograd (1998) - which represents the technological frontier, and wheat production as a measure of the relative productive specialisation and the reliance of productivity performance on the agricultural sector. The first variable captures the adjacency effect, while the second captures different kinds of specialisation processes in accordance with the staple theory (Watkins, 1963), in particular the relevance of the wheat boom in Canada.

The Appendix presents the computation process for all explanatory variables and their sources. The sample range corresponds to the years 1913-1983 due to data availability.

We applied ordinary least squares (OLS) with White heteroskedasticityconsistent standard errors and covariance and included an autoregressive term to control for autocorrelation in error terms ${ }^{8}$. We first estimated a model for the

8 It is important to note that Augmented Dickey Fuller (ADF) tests applied to the complete set of variables considered in the model suggest that all of them follow a I (1) process at 5 per cent, which implies the existence of a unit root and their first difference becomes stationary. An ambiguous result emerges from the ADF test on WHE; if ADF includes only 1 lag, the null hypothesis must be rejected, but 2 or more lags lead to the opposite conclusion. Considering information criteria in order to select an appropriate lag length, Akaike, Hannan-Quinn and their variants support that WHE could be described as I (1). The same integration order in series allows - at least potentially - long-term and stable relationships to emerge. In addition, Granger causality tests conducted on all variable-pairs support strong regressor exogeneity at 5 per cent. The results of both ADF and Granger causality tests are available upon request. 
TABLE 1

ECONOMETRIC REGRESSIONS. RELATIVE TOTAL FACTOR PRODUCTIVITY AS DEPENDENT VARIABLE

\begin{tabular}{|c|c|c|c|c|c|c|c|}
\hline \multirow{3}{*}{ GOV } & \multirow{3}{*}{$\begin{array}{c}\mathbf{1 9 1 3 - 1 9 8 3} \\
\mathbf{I} \\
0.036 \\
(0.3428)\end{array}$} & \multicolumn{2}{|c|}{ 1913-1939 } & \multirow{3}{*}{$\begin{array}{c}\text { III } \\
\begin{array}{c}0.103 \\
(0.0000)\end{array}\end{array}$} & \multirow{3}{*}{$\begin{array}{c}\mathbf{1 9 1 3 - 1 9 8 3} \\
\mathbf{I V} \\
\begin{array}{c}0.020 \\
(0.6062)\end{array}\end{array}$} & \multirow{3}{*}{$\begin{array}{c}\frac{1913-1934}{\mathbf{V}} \\
-0.313 \\
(0.4001)\end{array}$} & \multirow{3}{*}{$\begin{array}{c}\mathbf{1 9 3 5 - 1 9 8 3} \\
\mathbf{V I} \\
\begin{array}{c}0.099 \\
(0.0074)\end{array}\end{array}$} \\
\hline & & & & & & & \\
\hline & & $\begin{array}{c}-0.236 \\
(0.6562)\end{array}$ & $\begin{array}{c}-0.386 \\
(0.3489)\end{array}$ & & & & \\
\hline CIM & $\begin{array}{c}0.438 \\
(0.5832)\end{array}$ & $\begin{array}{c}0.9210 \\
(0.7497)\end{array}$ & $\begin{array}{c}-0.754 \\
(0.8162)\end{array}$ & $\begin{array}{c}0.058 \\
(0.8529)\end{array}$ & & & \\
\hline INF & $\begin{array}{c}-0.033 \\
(0.3134)\end{array}$ & $\begin{array}{c}0.700 \\
(0.4633)\end{array}$ & $\begin{array}{c}1.878 \\
(0.0342)\end{array}$ & $\begin{array}{c}-0.049 \\
(0.0047)\end{array}$ & $\begin{array}{c}0.004 \\
(0.8143)\end{array}$ & $\begin{array}{c}1.891 \\
(0.0166)\end{array}$ & $\begin{array}{c}-0.024 \\
(0.0249)\end{array}$ \\
\hline REG & $\begin{array}{c}-0.034 \\
(0.4290)\end{array}$ & $\begin{array}{c}-0.023 \\
(0.8293)\end{array}$ & $\begin{array}{c}0.046 \\
(0.7698)\end{array}$ & $\begin{array}{c}-0.002 \\
(0.9393)\end{array}$ & & & \\
\hline TAX & $\begin{array}{c}0.037 \\
(0.3307)\end{array}$ & $\begin{array}{c}0.271 \\
(0.4886)\end{array}$ & $\begin{array}{c}-0.113 \\
(0.6348)\end{array}$ & $\begin{array}{c}0.030 \\
(0.0863)\end{array}$ & & & \\
\hline USA & $\begin{array}{c}-0.003 \\
(0.0000)\end{array}$ & $\begin{array}{c}-0.003 \\
(0.4806)\end{array}$ & $\begin{array}{c}-0.007 \\
(0.0037)\end{array}$ & $\begin{array}{c}-0.001 \\
(0.0036)\end{array}$ & $\begin{array}{c}-0.003 \\
(0.0000)\end{array}$ & $\begin{array}{c}-0.006 \\
(0.0396)\end{array}$ & $\begin{array}{c}-0.001 \\
(0.0264)\end{array}$ \\
\hline WHE & $\begin{array}{c}0.360 \\
(0.0030)\end{array}$ & $\begin{array}{c}0.394 \\
(0.0665)\end{array}$ & $\begin{array}{c}0.509 \\
(0.0211)\end{array}$ & $\begin{array}{c}0.159 \\
(0.0295)\end{array}$ & $\begin{array}{c}0.398 \\
(0.0018)\end{array}$ & $\begin{array}{c}0.5853 \\
(0.0439)\end{array}$ & $\begin{array}{l}0.1727 \\
(0.005)\end{array}$ \\
\hline DWW & & & $\begin{array}{c}-1.540 \\
(0.0022)\end{array}$ & & $\begin{array}{c}-0.795 \\
(0.0000)\end{array}$ & $\begin{array}{l}-1.4693 \\
(0.0005)\end{array}$ & \\
\hline Observations & $70 !$ & $26^{!}$ & $26^{!}$ & 44 & $70 !$ & $21^{!}$ & 49 \\
\hline$R^{2}$ & 0.9072 & 0.5950 & 0.8048 & 0.8601 & 0.9202 & 0.8089 & 0.9596 \\
\hline F-statistic & $\begin{array}{c}74.593 \\
(0.0000)\end{array}$ & $\begin{array}{c}3.122 \\
(0.0231)\end{array}$ & $\begin{array}{c}7.332 \\
(0.0003)\end{array}$ & $\begin{array}{c}26.890 \\
(0.0000)\end{array}$ & $\begin{array}{l}121.147 \\
(0.0000)\end{array}$ & $\begin{array}{c}9.877 \\
(0.0002)\end{array}$ & $\begin{array}{l}204.398 \\
(0.0000)\end{array}$ \\
\hline
\end{tabular}


TABLE 1 (Cont.)

\begin{tabular}{|c|c|c|c|c|c|c|c|}
\hline & $1913-1983$ & \multicolumn{2}{|c|}{ 1913-1939 } & $1940-1983$ & 1913-1983 & 1913-1934 & $1935-1983$ \\
\hline & $\mathbf{I}$ & \multicolumn{2}{|c|}{ II } & III & IV & $\mathbf{V}$ & VI \\
\hline Akaike & 0.0891 & 1.2442 & 0.5911 & -1.9352 & -0.1189 & 0.6114 & -1.9239 \\
\hline White noise? & No & No & No & Yes & Yes & Yes & Yes \\
\hline $\begin{array}{l}\text { Breush-Godfrey } \\
\text { Serial Correl. LM } \\
\text { test }\end{array}$ & $\begin{array}{c}2.741 \\
(0.0727)\end{array}$ & $\begin{array}{c}4.066 \\
(0.0388)\end{array}$ & $\begin{array}{c}0.232 \\
(0.7959)\end{array}$ & $\begin{array}{c}0.208 \\
(0.8133)\end{array}$ & $\begin{array}{c}0.763 \\
(0.4710)\end{array}$ & $\begin{array}{c}0.097 \\
(0.9078)\end{array}$ & $\begin{array}{c}0.870 \\
(0.4265)\end{array}$ \\
\hline $\begin{array}{c}\text { White Heterosk. } \\
\text { Test }\end{array}$ & $\begin{array}{c}3.877 \\
(0.0002)\end{array}$ & $\begin{array}{c}1.261 \\
(0.3361)\end{array}$ & $\begin{array}{c}2.029 \\
(0.1218)\end{array}$ & $\begin{array}{c}0.825 \\
(0.6320)\end{array}$ & $\begin{array}{c}3.593 \\
(0.0013)\end{array}$ & $\begin{array}{c}0.436 \\
(0.8885)\end{array}$ & $\begin{array}{c}1.227 \\
(0.3088)\end{array}$ \\
\hline
\end{tabular}

Note: ${ }^{\dagger}$ All explanatory variables except REG and USA were expressed as country ratios. Type I errors are given in parentheses. Regressions also include an autoregressive term to control for autocorrelation in error terms.

'After adjusting endpoints.

Least squares White heteroskedasticity-consistent standard errors and covariance.

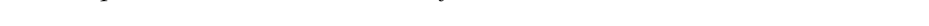


overall period. Results are presented in Table 1, column I. The $R^{2}$ is high (91 per cent); however, only the U.S. aggregate productivity (variable named USA) and the ratio between wheat productions (WHE) are statistically significant $(P<0.01)$. Moreover, residuals are not completely stationary; symptoms of autocorrelation and heteroskedasticity are also present. The existence of structural change in the parameters of the model could be the source of these problems. Following the results of the test of Zivot and Andrews on $\rho_{A}$, we re-estimated the model for the periods 1913-1939 and 1940-1983.

The results for the first subperiod (column II of Table 1) show only WHE with a statistically significant parameter, but the residuals continue to be non-stationary and present serial correlation. The possibility of relevant differences between Argentina and Canada with respect to the effects of the world wars is considered incorporating a dummy with value 1 for the war years (DWW). It shows a high significance for the first period improving the model substantially. The residual correlogram is fairly satisfactory; there is no serial autocorrelation and the variance is now homoscedastic. Only one of the proxies for social infrastructure is statistically significant, but has the opposite sign to the expected one.

There are no statistically relevant differences in integration in the world economy (TAX) for the period, or at least they have not operated to explain the evolution of $\rho_{A}(P>0.05)$. In contrast, the effect of the proximity with the technological frontier is the expected one (negative sign and $P<0.01$ ). Canada benefited from U.S. technological development during this period. Therefore, the more wheat oriented one economy became with respect to the other, the better the results were in terms of aggregate productivity (positive sign and $P<0.05$ ). Finally, the negative sign of DWW is explained by the fall in aggregate productivity in Argentina between 1915 and 1917 and the rise in Canada that began in 1914 and finished in 1917 (see graphs in Appendix).

We used the Wald test for redundant variables on the relative variables for polity regime (REG), contract intensive money (CIM), public expenditure (GOV) and integration (TAX), and concluded that these variables could be omitted $(P=0.812)$. Similar results are obtained substituting REG for the other polity variables.

The model behaves best in the second period, 1940-1983 (column III of Table 1). Residuals are white noise and do not present autocorrelation or heteroscedasticity. Social infrastructure is relevant and is captured by the estimated coefficient for GOV and INF. Results suggest that increased participation of public expenditure in GDP was positive in terms of productivity or, in other words, the aggregate productivity was supported by state activity. However, the macroeconomic mismanagements that accompanied particularly the actions of the Argentine government during several periods counteracted this effect. Differences in integration in the world economy (TAX) showed very low statistical significance $(P<0.10)$. Finally, despite the large differences in the political aspects between Argentina and Canada, none of the 
polity variables results are statistically relevant in explaining relative technological performance (the table shows the results of REG, but for POL (polity 2 index) and DEM (index of democracy) they do not differ substantially).

The Wald test on REG, CIM and TAX showed a $P=0.3759$ for Type I error. Thus, these variables were not relevant during the period under consideration (POL, CIM and TAX showed $P=0.366$, and DEM, CIM and TAX showed $P=0.372$ ). The utilisation of DWW is not statistically justified, and thus was omitted in advance.

Column IV of Table 1 shows that the results of the estimation for the complete range (1813-1983), omitting the statistically non-significant variables, do not change. Only USA and WHE have $P$-value below 0.05 and show the expected sign. DWW is statistically significant and does not change the sign with respect to the 1913-40 estimation. Residuals are stationary but heteroscedastic. Consequently, we used the Chow test for structural change.

The Chow test is commonly used instead of the test of Zivot and Andrews, which is a univariate model, to verify the existence of structural change in some or all of the parameters of a multivariate model in cases where the residual is assumed to be the same in both subperiods. The Chow test does not corroborate the structural change in $1940(P=0.102)$. The reason could be that at least one of the variables also experienced a structural change of a similar magnitude to that of $\rho_{A}$, and hence the residuals were not severely affected. Instead, the Chow test suggests that the structure of the model shows an appreciable change in $1935(P=0.053)$. The results of the estimation using the new periodisation did not change with respect to the previous one (see columns V and VI of Table 1).

\section{DISCUSSION}

Asencio (1995) said that trying to disentangle the Argentine enigma is not, unfortunately, an original question. Numerous approaches have been used. Some have simply looked at the Argentine case alone, while others have made comparisons with Canada, Australia, the United States and other countries. These comparative nations have, at least notionally, similar initial characteristics. It is not the purpose of this study to synthesise this discussion. Instead, the aim of this paper has been to present a new interpretation of the "Argentine failure» from a development accounting approach.

We showed that the development process of Canada (in terms of per capita GDP) moved away from that of Argentina around 1918, and that the recovery of Argentina - through improved performance of aggregate productivity - was not possible after 1940. There was a structural change in the determinants of aggregate productivity around 1935, which led Argentina to begin a divergent path, and broke off the relative technological performance path in 1940. After WWII, Canada became one of the most prosperous 
economies, while Argentina suffered the difficulties related with the continuity of the import substitution model, the stagnation of its production and high inflation. The results support this hypothesis.

The main result of this paper is that the technological performance of the United States affected the performance of Canada more positively than in the case of Argentina. A possible explanation could be geographical proximity and the inexistence of free availability of knowledge assuming that its cost rises with distance.

Nevertheless, another possible explanation could be the political alignment of Canada with the United States that facilitated the entry of U.S. enterprises with superior technological standards, or firms that were more prone to technological change motivated by the size of the Commonwealth market and the enactment of the Imperial Preference of 1932 (Lucchini 2006). Finally, Canada moved away from confrontation with the United States with the enactment of the Reciprocal Trade Agreements Act in 1934 (Pomfret 2000), while Argentina tried to reinforce the Anglo-Argentine connection with the enactment of the Roca-Runciman agreement in 1932 (Rapoport 1994). Argentina gradually moved away from the United States, principally during and after WWII (Gerchunoff and Fajgelbaum 2006).

The quantitative effect of these dissimilar political decisions could be confused with the effect of adjacency previously considered. Thus, the incorporation of a third country is methodologically justified: Australia seems to occupy an intermediate situation between the adjacent and (politically) close Canada and the remote and (politically) distant Argentina. The remote Australia turned into a close political partner of Washington during the long Cold War and, in particular, during WWII, while Argentina preferred to remain neutral and distant (Gerchunoff and Fajgelbaum 2006; Esposto and Tohmé 2009). Some research has been done to isolate the effects of the political decisions on aggregate productivity, but results are very preliminary (González 2010).

The robustness of the positive parameters for the ratio between Argentine and Canadian wheat production, and the considerably lower value for the second period (independently of the precise definition of the subperiod) suggests that the Wheat Boom in Canada had a long-run effect, while Argentina seems to have fallen into a «staple trap» following the terminology of Watkins (1963) and the work of Altman (2003). This thesis reinforces the previous interpretation.

\section{REFERENCES}

Acemoglu, D. (2008): Introduction to Modern Economic Growth. Princeton, NJ: Princeton University Press.

Altman, M. (2003): «Staple Theory and Export-Led Growth: Constructing Differential Growth». Australian Economic History Review 43 (3), pp. 230-255. 
Asencio, M. (1995): Argentina y los otros. Historia económica del fracaso y el éxito. Buenos Aires: Ediciones Corregidor.

Blyde, J., and Fernández-Arias, E. (2005): "Why Latin America is Falling Behind», in E. Fernández-Arias, R. Manuelli, and J. Blyde (eds), Sources of Growth in Latin America. Washington, D.C.: Inter-American Development Bank, pp. 3-54.

CASELLI, F. (2005): «Accounting for Cross-Country Income Differences», in P. Aghion, and S. Durlauf (eds), Handbook of Economic Growth, vol. 1A, New York: Elsevier, pp. 679-742.

Della Paolera, G., and Taylor, A. (2003): A New Economic History of Argentina. Cambridge: Cambridge University Press.

Engerman, S., and SoKoloff, K. (2003): «Institutional and Non-Institutional Explanations of Economic Differences», NBER Working Paper Series no. 9989.

Esposto, A., and ToнmÉ, F. (2009): Drifting Apart: The Divergent Development Paths of Argentina and Australia. Saarbrücken: VDM Verlag Dr. Müller Aktiengesellschaft \& Co. KG.

FERREREs, O. (2005): Dos siglos de economía argentina (1810-2004). Historia argentina en cifras. Buenos Aires: Fundación Norte y Sur.

GALOR, O. (1996): «Convergence? Inferences from Theoretical Models». Economic Journal 106, pp. 1056-1069.

Gerchunoff, P., and Fajgelbaum, P. (2006): ¿Por qué Argentina no fue Australia? Una hipótesis sobre un cambio de rumbo. Buenos Aires: Siglo XXI.

Gollin, D. (2002): «Getting Income Shares Right». Journal of Political Economy 110 (2), pp. $458-474$.

GonzÁlez, G. (2010): «Effects of Adjacency and Political Proximity with United States of America on the Canadian, Australian and Argentine Economic Performances", unpublished, Bahía Blanca: Instituto de Investigaciones Económicas y Sociales.

GonZÁLeZ, G., and Constantin, S. (2009): «Efectos de la apertura sobre el crecimiento cuando se tiene en cuenta el contexto». Revista de Ciencias Económicas XXVII (2), pp. 11-20.

GonzÁLEZ, G., and VIEGo, V. (2008): «Deep Determinants of Relative Per-Capita GDPs, Argentina-Canada from 1870». Anales de la Asociación Argentina de Economía Política XLIII Reunión Anual.

González, G.; Dabús, C., and Monterubbianesi, P. (2011): «Phases of Convergence in Latin America: The Technological Drivers». Journal of International Development. doi:10.1002/jid.1803.

Hall, R., and Jones, C. (1997): «What Have We learned from Recent Empirical Growth Research? Levels of Economic Activity Across Countries». American Economic Review 87 (2, Papers and Proceedings of the Hundred and Fourth Annual Meeting of the American Economic Association, pp. 173-177.

Hall, R., and Jones, C. (1999): «Why Do Some Countries Produce So Much More Output Per Worker than Others?». Quarterly Journal of Economics 114 (1), pp. 83-116.

Hopenhayn, H., and Neumeyer, P. (2004): «Latin America in XXth Century: Stagnation, Then Collapse», in E. Fernandez-Arias, R. Manuelli, and J. Blyde (eds), Sources of growth in Latin America. What is missing? Appendix B. Washington, D.C.: InterAmerican Development Bank.

Hsien, C., and Klenow, P. (2010): «Development Accounting». American Economic Journal: Macroeconomics 2 (1), pp. 207-223.

KATZ, S.; LANTERI, L., and VARGAS, S. (2007): «Un vínculo sutil y no siempre comprendido en medio siglo: una nota sobre la tasa de inversión y el crecimiento económico». Ensayos Económicos 47, pp. 7-62.

King, R., and Levine, R. (1994): «Capital Fundamentalism, Economic Development, and Economic Growth». Carnegie-Rochester Conference Series on Public Policy 40 (June), pp. 259-292. 
Klenow, P., and Rodriguez-Claire, A. (1997): «The Neoclassical Revival in Growth Economics: Has It Gone Too Far?», in B. Bernanke, and J. Rotemberg (eds), NBER Macroeconomics Annual, vol. 12. Cambridge: MIT Press, pp. 73-102.

KNeller, R. (2005): «Frontier Technology, Absorptive Capacity and Distance». Oxford Bulletin of Economics and Statistics 67 (1), pp. 1-23.

LucchinI, C. (2006): Estrategias de desarrollo, industria y estado en Canadá 1919-1939. Buenos Aires: Siglo XXI.

Maddison, A. (2006): The World Economy, Development Centre Studies. Paris: OECD Publishing.

Mankiw, N. G.; Romer, D., and Weil, D. (1992): "A Contribution to the Empirics of Economic Growth». Quarterly Journal of Economics 107 (2), pp. 407-437.

Manuelli, R. (2005): «Growth in Latin America: Empirical Findings and Some Simple Theoretical Explanations», in E. Fernandez-Arias, R. Manuelli, and J. Blyde (eds), Sources of Growth in Latin America. What is Missing?. Washington, D.C.: InterAmerican Development Bank.

Miguez, E. (2005): «'El fracaso argentino’. Interpretando la evolución económica en el 'corto siglo XX'». Desarrollo Económico 44 (176), pp. 483-514.

Miller, S., and Upadhyay, M. (2000): «The Effects of Openness, Trade Orientation, and Human Capital on Total Factor Productivity». Journal of Development Economics 63, pp. 399-423.

Pomfret, R. (2000): «Trade Policy in Canada and Australia in the Twentieth Century». Australian Economic History 40 (2), pp. 114-126.

Prados de la Escosura, L., and Sanz-Villarroya, I. (2009): "Contract Enforcement, Capital Accumulation, and Argentina's Long-Run Decline». Cliometrica 3, pp. 1-26.

RAPOPORT, M. (1994): «La inserción internacional de Argentina y Canadá: Un análisis histórico comparado», in M. Rapoport (ed.), Globalización, Integración e Identidad Nacional. Análisis comparado Argentina-Canadá. Buenos Aires: Grupo Editor Latinoamericano, pp. 175-209.

Rodriguez, F. (2005): «The Political Economy of Latin American Economic Growth», in E. Fernandez-Arias et al. (eds), Sources of growth in Latin America. What is missing? Appendix C. Washington, D.C.: Inter-American Development Bank.

Rodríguez, F., and Rodrik, D. (2000): «Trade Policy and Economic Growth: A Skeptic's Guide to the Cross-National Evidence», in B. Bernanke, and K. Rogoff (eds), NBER Macroeconomics Annuals 2000. Cambridge: MIT Press, pp. 261-338.

RodriK, D. (2003): «What Do We Learn from Country Narratives?», in Rodrik, D. (ed.), In search of Prosperity, Analytic Narratives on Economic Growth. Princeton, NJ: Princeton University Press, Chapter 1, pp. 1-19.

Sanz-Villarroya, I. (2005): «The Convergence Process of Argentina with Australia and Canada: 1875-2000». Explorations in Economic History 42 (3), pp. 439-458.

SEN, A. (2003): «On Unit Root Tests When the Alternative Is A Trend Break Stationary Process». Journal of Business and Economic Statistics 21, pp. 174-184.

VÉGanzonès, M., and WinogRad, C. (1998): «Human Capital, Trade Openness and Growth in Argentina in the 20th Century». Labour 12 (2), pp. 305-352.

Watkins, M. (1963): "A Staple Theory of Economy Growth». Canadian Journal of Economics and Political Science XXIX (2), pp. 141-158.

Zivot, E., and ANDrews, D. (1992): «Further Evidence on the Great Crash, the Oil-Price Shock and the Unit-Root Hypothesis». Journal of Business and Economic Statistics 10 (3), pp. 251-270. 


\section{APPENDIX}

\section{Sources and estimation process}

For the first stage - that is, the estimation and decomposition of the developing gap - the raw data are taken from various sources. The following table summarises the construction of the series for the period 1895-1995:

TABLE A1

\begin{tabular}{|c|c|c|}
\hline Argentina series & Sources & \\
\hline $\begin{array}{l}\text { GDP (U.S.\$1990 } \\
\text { Geary Khamis) }\end{array}$ & $1895-1995$ & Ferreres (op. cit.) \\
\hline $\begin{array}{l}\text { Total population } \\
\text { (persons) }\end{array}$ & 1895-1995 & Ferreres (op. cit.) \\
\hline \multirow[t]{4}{*}{$\begin{array}{l}\text { Employed population } \\
\text { (persons) }\end{array}$} & 1895 & $\begin{array}{l}\text { INDEC, Censo Nacional } 1895 \text { (cadre } \\
\text { XXVId) }\end{array}$ \\
\hline & 1913-1995 & Ferreres (op. cit.) \\
\hline & $1900-1912$ & $\begin{array}{l}\text { Estimated using the growth rates of } \\
\text { Veganzones and Winograd (op. cit.)' } \\
\text { serie I }\end{array}$ \\
\hline & 1896-1899 & $\begin{array}{l}\text { Assuming that the growth rate of } \\
\text { population is similar to growth rate } \\
\text { of population between } 15 \text { and } 64 \text { years } \\
\text { old, we use the series of Taylor and } \\
\text { Williamson presented in Della Paolera } \\
\text { and Taylor's data set (op. cit.) }\end{array}$ \\
\hline \multirow{3}{*}{$\begin{array}{l}\text { Human capital stock } \\
\text { (U.S.\$ } 1990 \text { Geary } \\
\text { Khamis) }\end{array}$} & \multirow[t]{3}{*}{ 1895-1995 } & $\begin{array}{l}\text { Estimated following the methodology of } \\
\text { Mankiw et al. (op. cit.) }\end{array}$ \\
\hline & & $\begin{array}{l}\text { For } 1895 \text { we assume that } \mathrm{H}=(\mathrm{H} / \mathrm{Y}) \text { st } \times \\
\mathrm{GDP} \times(1-\text { delta })+\text { human capital } \\
\text { investment }\end{array}$ \\
\hline & & $\begin{array}{l}\text { We assume that the ratio human capital/ } \\
\text { product ratio in steady state is }(\mathrm{H} / \mathrm{Y}) \text { st }= \\
\text { (HI/Y)st/( } n+\text { gst }+ \text { delta) where }(\mathrm{HI} / \mathrm{Y}) \text { st } \\
\text { is the human capital investment share in } \\
\text { steady state, estimated as the simple } \\
\text { average of the human capital investment } \\
\text { rate for the whole period (1895-1995). } \\
\text { Parameter } n \text { is the annual growth rate } \\
\text { between } 1895 \text { and } 1995 \text { (Maddison } 2006) \text {, } \\
\text { and parameter delta is the depreciation } \\
\text { rate equals to } 0.07 \text {. The parameter gst is } \\
\text { the growth rate of steady state, and we } \\
\text { assume that is equals to the weighted }\end{array}$ \\
\hline
\end{tabular}


TABLE A1 (Cont.)

\begin{tabular}{|c|c|c|}
\hline & & $\begin{array}{l}\text { average between the World GDP growth } \\
\text { rate and the own annual GDP growth rate } \\
\text { for the whole period } \\
\text { The World GDP growth rate is estimated } \\
\text { using the Maddison (2006) World GDP } \\
\text { for } 1890 \text { and 1995; and have a weight } \\
\text { of } 0.25 \text { in the computation of gst. } \\
\text { The proper annual GDP growth rate is } \\
\text { computed using Ferreres (op. cit.) and } \\
\text { have a weight of } 0.75 \text { The human capital } \\
\text { investment share (HI/Y) is computed } \\
\text { as the ratio between the secondary } \\
\text { enrolment and the population between } \\
15 \text { and } 64 \text { years old. Hence, the human } \\
\text { capital investment in U.S. } \$ \text { is computed } \\
\text { multiplying I/Y by GDP } \\
\text { For } 1896-1995 \text {, the computation of H is } \\
\text { the usual: the previous H multiplied by } \\
\text { (1-delta) and adding the present } \\
\text { human capital investment }\end{array}$ \\
\hline $\begin{array}{l}\text { Physical capital stock } \\
\text { (U.S.\$ } 1990 \text { Geary } \\
\text { Khamis) }\end{array}$ & 1895-1995 & $\begin{array}{l}\text { Estimated following King and Levine } \\
\text { (op. cit.). The parameter values and } \\
\text { estimation process is similar to the } \\
\text { human capital stock } \\
\text { For } 1895 \text { we assume that } \mathrm{K}=(\mathrm{K} / \mathrm{Y}) \text { st } \times \\
\text { GDP } \times(1-\text { delta) }+ \text { physical capital } \\
\text { investment, } \\
\text { where }(\mathrm{K} / \mathrm{Y}) \text { st is equal to }(\mathrm{I} / \mathrm{Y}) \text { st / } \\
(\mathrm{n}+\text { gst }+ \text { delta) and }(\mathrm{I} / \mathrm{Y}) \text { st is the } \\
\text { average of the annual investment rate } \\
\text { for the whole period } \\
\text { Between } 1896 \text { and } 1995 \text {, the estimation } \\
\text { process for } \mathrm{K} \text { is the usual: the previous } \\
\text { K multiplied by ( } 1-\text { delta) and adding } \\
\text { the present physical capital investment }\end{array}$ \\
\hline $\begin{array}{l}\text { Population between } \\
15 \text { and } 64 \text { years old } \\
\text { (persons) }\end{array}$ & $\begin{array}{c} \\
1915 / 1920 / 1925 / \\
1930 / 1935 / \\
1940 / 1945 / \\
1950 / 1955\end{array}$ & $\begin{array}{l}\text { Estimated using the growth rates of } \\
\text { Taylor and Williamson's series } \\
\text { presented in Della Paolera and } \\
\text { Taylor's data set (op. cit.) } \\
\text { Vazquez-Presedo, V. (1988) ESTADISTI- } \\
\text { CAS HISTORICAS ARGENTINAS, } \\
\text { Compendio 1873-1973, Instituto de } \\
\text { Economía Aplicada, Academia Nacional } \\
\text { de Ciencias Económicas }\end{array}$ \\
\hline
\end{tabular}


TABLE A1 (Cont.)

\begin{tabular}{|c|c|c|}
\hline \multirow[t]{2}{*}{ Argentina series } & Sources & \\
\hline & $\begin{array}{c}\text { For missing data } \\
\text { between } 1915 \\
\text { and } 1960 \\
1960-1995\end{array}$ & $\begin{array}{l}\text { We use the growth rates of the Taylor and } \\
\text { Williamson's presented in Della Paolera } \\
\text { and Taylor's data set (op. cit.) } \\
\text { World Bank, World Databank, Health } \\
\text { Nutrition and Population Statistics }\end{array}$ \\
\hline \multirow{9}{*}{$\begin{array}{l}\text { Secondary enrolment } \\
\text { (pupils) }\end{array}$} & $1895-1913$ & Bank's data set \\
\hline & 1914 & $\begin{array}{l}\text { Estimated using the growth rate of the } \\
\text { series presented in OxLAD data set }\end{array}$ \\
\hline & $\begin{array}{c}1915 / 1920 / 1925 / \\
1930 / 1935\end{array}$ & Ferreres (op. cit.) \\
\hline & $\begin{array}{l}\text { Missing data } \\
\text { between } 1915 \\
\text { and } 1940\end{array}$ & $\begin{array}{l}\text { Estimated using the growth rates of the } \\
\text { series presented in the Bank's data set }\end{array}$ \\
\hline & 1940-1988/1994 & Ferreres (op. cit.) \\
\hline & 1989 & $\begin{array}{l}\text { Simple average between the values for } \\
1988 \text { and } 1990\end{array}$ \\
\hline & 1990-1991 & OxLAD data set \\
\hline & $1992-1993$ & $\begin{array}{l}\text { Assuming geometrical growth rate, we } \\
\text { estimate the missing data using the } \\
\text { values for } 1991 \text { y } 1994 \text {. }\end{array}$ \\
\hline & 1995 & $\begin{array}{l}\text { Simple average between the values for } \\
1994 \text { y } 1996\end{array}$ \\
\hline \multirow{2}{*}{$\begin{array}{l}\text { Gross investment } \\
\text { share on GDP } \\
\text { (current prices, \%) }\end{array}$} & $1895-1992$ & $\begin{array}{l}\text { Taylor, A. «Capital Accumulation» in } \\
\text { Della Paolera, G. and A. Taylor (op. cit.) }\end{array}$ \\
\hline & 1993-1995 & OxLAD data set \\
\hline Canada series & Sources & \\
\hline $\begin{array}{l}\text { GDP (U.S.\$1990 } \\
\text { Geary Khamis) }\end{array}$ & $1895-1995$ & Ferreres (op. cit.) \\
\hline $\begin{array}{l}\text { Total population } \\
\text { (persons) }\end{array}$ & $1895-1920$ & $\begin{array}{l}\text { Statistics Canada (1983) Historical } \\
\text { Statistics of Canada, second edition } \\
\text { (Series A1) }\end{array}$ \\
\hline $\begin{array}{l}\text { Employed population } \\
\text { (persons) }\end{array}$ & $\begin{array}{r}1901 / 1911 / \\
1921-1945\end{array}$ & $\begin{array}{l}\text { Statistics Canada (1983) Historical } \\
\text { Statistics of Canada, second edition } \\
\text { (Series D2-124-133) }\end{array}$ \\
\hline
\end{tabular}


TABLE A1 (Cont.)

\begin{tabular}{|c|c|c|}
\hline & $\begin{array}{l}\text { Missing data } \\
\text { between } 1895 \\
\text { and } 1921 \\
1946-1975 \\
1976-1995\end{array}$ & $\begin{array}{l}\text { Estimated using the growth rates of the } \\
\text { total population since the published } \\
\text { value for } 1891 \text { (SC, HSC). } \\
\text { Statistics Canada, CANSIM } \\
\text { (Table 380-0044) } \\
\text { Statistics Canada, CANSIM } \\
\text { (Table 282-0002) }\end{array}$ \\
\hline $\begin{array}{l}\text { Human capital stock } \\
\text { (U.S.\$ } 1990 \text { Geary } \\
\text { Khamis) }\end{array}$ & $1895-1995$ & Idem Argentina \\
\hline $\begin{array}{l}\text { Physical capital stock } \\
\text { (U.S.\$ } 1990 \text { Geary } \\
\text { Khamis) }\end{array}$ & 1895-1995 & Idem Argentina \\
\hline \multirow[t]{4}{*}{$\begin{array}{l}\text { Population between } \\
15 \text { and } 64 \text { years old } \\
\text { (persons) }\end{array}$} & $1891 / 1901 / 1911$ & $\begin{array}{l}\text { Statistics Canada (1983) Historical } \\
\text { Statistics of Canada, second edition } \\
\text { (Series A82-91) }\end{array}$ \\
\hline & $\begin{array}{l}\text { Missing data } \\
\text { between } 1895 \\
\text { and } 1921\end{array}$ & $\begin{array}{l}\text { Using the growth rate of total population } \\
\text { since de published value for } 1891 \\
\text { (SC, HSC) }\end{array}$ \\
\hline & 1921-1971 & $\begin{array}{l}\text { Statistics Canada, CANSIM } \\
\text { (Table 051-0026) }\end{array}$ \\
\hline & 1972-1995 & $\begin{array}{l}\text { Statistic Canada, CANSIM } \\
\text { (Table 051-0001) }\end{array}$ \\
\hline \multirow[t]{3}{*}{$\begin{array}{l}\text { Secondary enrolment } \\
\text { (pupils) }\end{array}$} & $\begin{array}{c}1895-1913 / \\
1919-1939 / \\
1946-1979\end{array}$ & Bank's data set \\
\hline & $\begin{array}{r}1914-1918 / \\
1940-1944\end{array}$ & $\begin{array}{l}\text { Estimated using the growth rates } \\
\text { of the series presented in the Canada } \\
\text { Year Book, Historical Collection } \\
\text { of Statistics Canada }\end{array}$ \\
\hline & 1980-1995 & $\begin{array}{l}\text { World Bank, World Databank, } \\
\text { Educational Statistics }\end{array}$ \\
\hline \multirow{2}{*}{$\begin{array}{l}\text { Gross investment } \\
\text { share on GDP } \\
\text { (current prices, \%) }\end{array}$} & 1895-1994 & $\begin{array}{l}\text { McInnis, M. (2001) Historical Canadian } \\
\text { Macroeconomic Dataset 1871-1994 }\end{array}$ \\
\hline & 1995 & $\begin{array}{l}\text { Statistics Canada, CANSIM } \\
\text { (Table 380-0017) }\end{array}$ \\
\hline
\end{tabular}


The following table summarises the sources of the series for the second stage - that is, the econometrical approach to the sources of technological gap - for the period 1913-1983. Except where indicated, the variables express the ratio Argentina vis-à-vis Canada:

TABLE A2

\begin{tabular}{|c|c|c|}
\hline $\begin{array}{l}\text { Social infra- } \\
\text { structure series }\end{array}$ & & References and sources \\
\hline $\begin{array}{l}\text { Government } \\
\text { expenditure }\end{array}$ & GOV & $\begin{array}{l}\text { The country variable is the ratio between the } \\
\text { government expenditure and the GDP. Then, } \\
\text { GOV is the ratio between the country variables } \\
\text { Argentina: Ferreres (op. cit.) } \\
\text { Canada: McInnis (op. cit.) }\end{array}$ \\
\hline $\begin{array}{l}\text { Contract intensive } \\
\text { money }\end{array}$ & CIM & $\begin{array}{l}\text { The country variable is the ratio between the total } \\
\text { deposits in banks and M2; this last variable is the } \\
\text { currency outside and inside banks. CIM is the ratio } \\
\text { between the country variables } \\
\text { Argentina: Della Paolera y Taylor data set } \\
\text { Canada: Statistics Canada, HSC (Series J1-10) and } \\
\text { Statistics Canada, CANSIM (Table 176-00201) }\end{array}$ \\
\hline Inflation & INF & $\begin{array}{l}\text { Ratio between the inflation index for both countries. } \\
\text { Inflation index }=1+\text { inflation rate } / 100 \text { with } 1999=1 \\
\text { Argentina: Ferreres (op. cit.) Canada: Statistics } \\
\text { Canada, CANSIM }\end{array}$ \\
\hline $\begin{array}{l}\text { Government } \\
\text { regime }\end{array}$ & REG & $\begin{array}{l}\text { A dummy variable that takes the value } 1 \text { for years } \\
\text { with any government controlled by a non-military } \\
\text { component of the nation's population and } 0 \text { otherwise. } \\
\text { Canada shows value } 1 \text { for the whole period } \\
\text { The Anthony Bank's data set presents this variable } \\
\text { with four possible values: (1) civilian, (2) military- } \\
\text { civilian, (3) military and (4) other } \\
\text { For Argentina, we reduced it to a dichotomy variable } \\
\text { taken (1) civilian and (0) other. We completed the } \\
\text { dataset for the war years and changed the values to } \\
\text { the periods 1930-1931, 1955-1957 and 1976-1982 } \\
\text { originally assigned with values (2) and (3) }\end{array}$ \\
\hline Polity 2 index & POL & $\begin{array}{l}\text { Kristian Skrede Gleditsch, Polity Data Archive, } \\
\text { Polity IV project } \\
\text { Polity scale ranges from }+10 \text { (strongly democratic) } \\
\text { to }-10 \text { (strongly autocratic) }\end{array}$ \\
\hline
\end{tabular}


TABLE A2 (Cont.)

\begin{tabular}{|c|c|c|}
\hline & & $\begin{array}{l}\text { The variable is a composite index derived from the } \\
\text { coded values of authority characteristic component } \\
\text { variables } \\
\text { POL is the ratio between the Polity values for } \\
\text { both countries }\end{array}$ \\
\hline Index of democracy & DEM & $\begin{array}{l}\text { Vanhanen, T. (2002) Polyarchy Dataset. Measures } \\
\text { of Democracy 1810-2002, second version } \\
\text { The country variable is the combination of two } \\
\text { indices: electoral participation and electoral } \\
\text { competition. The first one is measured as the } \\
\text { percentage of the total population which actually } \\
\text { voted in the same election while the second is } \\
\text { defined as the smaller parties' share of the votes cast } \\
\text { in parliamentary of presidential elections or both. } \\
\text { The two indicators are combined into an index by } \\
\text { multiplying them and dividing the outcome by } 100 \\
\text { DEM is the ratio between the country variables }\end{array}$ \\
\hline Integration series & & References and sources \\
\hline $\begin{array}{l}\text { Average taxes to } \\
\text { imports }\end{array}$ & TAX & $\begin{array}{l}\text { Ratio between the average taxes to mports (AVE) } \\
\text { of each country } \\
\text { AVE = axes to mports (current prices)/mports } \\
\text { (current prices) Argentina: Ferreres (op. cit) and } \\
\text { Della Paolera and Taylor data set Canada: McInnis } \\
\text { (op. cit.) and Statistics Canada, HSC }\end{array}$ \\
\hline $\begin{array}{l}\text { Geography } \\
\text { series }\end{array}$ & & References and sources \\
\hline $\begin{array}{l}\text { U.S. total factor } \\
\text { productivity }\end{array}$ & USA & It is not a ratio. Véganzonès and Winograd (op. cit.) \\
\hline Wheat production & WHE & $\begin{array}{l}\text { Ratio between the Wheat production (000 ton) of } \\
\text { each country } \\
\text { Argentina: Ferreres (2005) } \\
\text { Canada: Statistics Canada, CANSIM (Table 001-0010) }\end{array}$ \\
\hline
\end{tabular}


Evolution of the components of the production function by country

FIGURE A-1
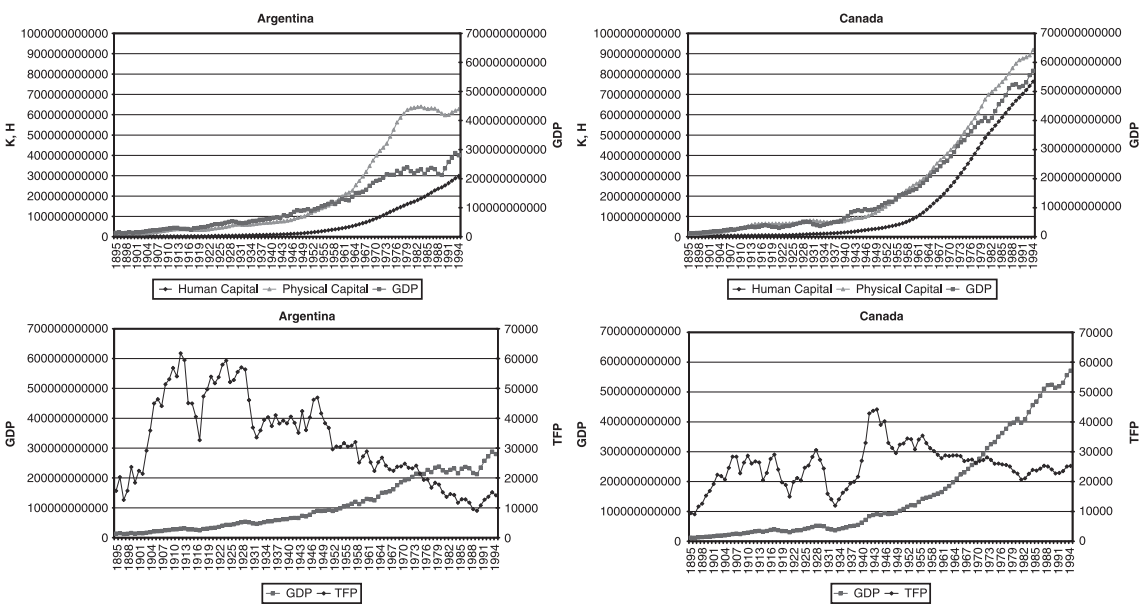

Source: Authors' estimations. 